\title{
JAZF1/SUZ12 Fusion Protein
}

National Cancer Institute

\section{Source}

National Cancer Institute. AAZF1/SUZ12 Fusion Protein. NCI Thesaurus. Code C99708.

A fusion protein encoded by the JAZF1/SUZ12 fusion gene. This protein is predicted to contain the extreme $\mathrm{N}$-terminus of the juxtaposed with another zinc finger protein 1 protein fused to most of the polycomb protein SUZ12. 